\title{
DIGLOSIA
}

Terakreditasi Sinta 3 | Volume 3 | Nomor 3 | Tahun 2020 | Halaman 305-316

P-ISSN 2615-725X | E-ISSN 2615-8655

http://diglosiaunmul.com/index.php/diglosia/article/view/103

\section{KONSISTENSI STRUKTUR ARGUMENT BY COMMITMENT DALAM EDITORIAL HARIAN BISNIS INDONESIA: PERSPEKTIF DOUGLAS WALTON}

\author{
Argument by Commitment Construction Consistency in Editorial Rubrics of Bisnis Indonesia Daily \\ News: Douglas Walton Perspective
}

\author{
Pilipus Wai Lawet ${ }^{1}$ dan Yuliana Setyaningsih ${ }^{2}$ \\ ${ }^{1,2}$ Fakultas Keguruan dan Ilmu Pendidikan \\ Universitas Sanata Dharma Yogyakarta \\ ${ }^{1}$ Pos-el: lawetj209@gmail.com \\ ${ }^{2}$ Pos-el korespondensi: yuliapbsi@gmail.com
}

\begin{abstract}
Consistency is very essential in writing editorial rubrics because it shows commitments of the author and his institution. Author and media institution who have high commitments in writing editorial argumentation can increase the level of readers' confidence toward the content of editorials. This research is intended to optimize the consistency of the construction of argument by commitment in Bisnis Indonesia editorials. Data collection methods used were documentation and interview methods. The research data were in the form of editorial texts containing arguments. The data analysis method used was the qualitative data analysis. Besides, the content analysis method was also applied. The research result showed that there were inconsistencies of arguments by commitment used in the editorials. The inconsistencies occured because a deep understanding of the concept of argument by commitment in writing editorials has not been understood well by editorial writers. Therefore, the steps of optimizing the consistency of argument by commitment must be done as follows: (1) understanding the concept of argument by commitment, (2) designing an argument by commitment scheme, and (3) asking critical questions.
\end{abstract}

Keywords: Bisnis Indonesia editorial, concistency, optimalization, argument by commitment, Douglas Walton

\begin{abstract}
Abstrak: Konsistensi sangat penting dalam penulisan rubrik editorial karena hal tersebut menunjukkan komitmen penulis dan institusinya. Penulis dan lembaga media yang memiliki komitmen tinggi dalam menulis argumentasi pada editorial dapat meningkatkan tingkat kepercayaan pembaca terhadap substansi editorial. Penelitian ini bertujuan untuk mengoptimalisasikan konsistensi konstruksi argument by commitment dalam editorial harian Bisnis Indonesia. Metode pengumpulan data yang digunakan adalah metode dokumentasi dan wawancara. Data penelitian ini berupa teks-teks editorial yang mengandung argumentasi. Metode analisis data yang digunakan adalah analisis data kualitatif. Selain itu, metode analisis isi juga diterapkan dalam penelitian ini. Hasil penelitian menunjukkan terdapatnya inkonsistensi argument by commitment yang digunakan dalam editorial harian Bisnis Indonesia. Inkonsistensi tersebut terjadi karena belum dipahaminya secara mendalam konsep argument by commitment dalam penulisan editorial oleh para penulis tajuk. Oleh karena itu, langkah-langkah optimalisasi konsistensi argument by commitment dapat dilakukan melalui langkah berikut: (1) memahami konsep argument by commitment, (2) merancang skema argument by commitment, dan (3) mengajukan pertanyaan-pertanyaan kritis.
\end{abstract}

Kata kunci: editorial Bisnis Indonesia, konsistensi, optimalisasi, argument by commitment,

Douglas Walton 


\section{A. PENDAHULUAN}

Argumentasi sangat penting dalam penulisan editorial media massa. Argumentasi dalam editorial bertujuan untuk memengaruhi sikap dan pendapat pembaca agar percaya dan bertindak sesuai dengan apa yang diinginkan penulis editorial. Pandangan tersebut sejajar dengan pernyataan Al-Khatib et al. (2016) bahwa editorial merupakan salah satu jenis tulisan argumentatif yang tujuan utamanya adalah memengaruhi. Senada dengan itu, Tim Buku Kompas (2008) menyatakan bahwa argumentasi adalah penulisan yang bertujuan menyakinkan orang, membuktikan pikiran atau pendapat pribadi, atau bahkan membujuk pihak lain agar pendapat pribadi penulis diterima. Upaya meyakinkan pembaca dilakukan dengan mengedepankan buktibukti atau fakta yang mendukung sehingga pembaca merasa yakin dengan apa yang disampaikan. Semakin banyak bukti-bukti yang diajukan dalam argumentasi di editorial, semakin tinggi tingkat kepercayaan pembaca terhadap pandangan media massa.

Argumentasi dalam editorial dapat dikategorikan sebagai argumentasi monologis. Hunter (2007) menyatakan bahwa hal tersebut merupakan pengumpulan pengetahuan untuk membangun argumentasi dan kesimpulan tertentu. Argumentasi monologis menunjukkan proses internal dalam diri penulis editorial dengan hasil nyata seperti artikel, pembicaraan, dan keputusan tertentu. Dalam argumentasi monologis tidak terdapat dialog antara dua agen yang terlibat dalam sebuah pembicaraan. Argumentasi monologis bersifat statis (Hunter, 2007). Hal inilah yang membedakan argumentasi dalam editorial dengan argumentasi dalam debat atau diskusi.

Editorial merupakan mahkota halaman redaksi (Siregar, 2002). Sebagai mahkota, editorial mengindikasikan kekuatan atau kelemahan sebuah media (Rivers, 2004).
Hal ini diperkuat dengan pernyataan Anggara (2015) dan Padiatra (2018) bahwa identitas media massa dapat dilihat dalam editorial. Di samping itu, tercermin pula pada motto, ukuran kertas, gaya penulisan, gaya bahasa, isi pemberitaan. Selain itu, Siregar (2002) menegaskan bahwa editorial secara eksplisit menyajikan visi dan misi media kepada pembaca. Melalui editorial pembaca dapat menangkap visi dan misi yang hendak diusung media massa. Pandangan ini sejalan dengan pernyataan Djuroto (2004) bahwa editorial menggambarkan falsafah dan pandangan penerbitnya. Falsafah dan pandangan hidup surat kabar ditunjukkan secara implisit maupun eksplisit dalam editorial.

Penelitian tentang artikel opini telah beberapa kali dilakukan. Pertama penelitian Hasanah \& Dawud (2017) berjudul "Argumentasi dalam Artikel Opini Surat Kabar Media Indonesia" yang menyimpulkan bahwa (1) metode argumentasi dapat berupa metode pembuktian dengan pendefinisian, sebab dan akibat, persamaan, pertentangan, perbandingan, kesaksian, dan otoritas, (2) pola argumentasi dapat berbentuk pola sederhana dan pola kompleks. Adapun, penelitian Pratama \& Dawud berjudul Teks Tanggapan Kritis dalam Surat Kabar Harian Jawa Pos (Online) mengungkapkan bahwa (1) wujud tanggapan kritis dapat diklasifikasikan berdasarkan isi kalimat dan/atau paragraf berupa kritik, saran, ajakan, dan pendapat penulis, (2) tataran wujud tanggapan kritis dapat diklasifikasikan berdasarkan alas kritik, ajakan, dan pendapat penulis.

Selain itu, penelitian yang dilakukan oleh Pertiwi (2018) berjudul Argumentasi dalam Teks Editorial Harian Suara Merdeka menyimpulkan bahwa (1) teknik argumentasi terdiri atas rasionalisasi, identifikasi, sugesti, konformitas, kompensasi, penggantian, proyeksi, (2) pola argumentasi dapat berbentuk pola rasionalisasi, identifikasi, sugesti, 
konformitas, kompensasi, penggantian, proyeksi.

Ketiga penelitian di atas juga berfokus pada argumentasi dalam editorial, tetapi tidak bersentuhan dengan persoalan konsistensi dan inkonsistensi argumen dalam editorial di media massa. Hal ini menegaskan bahwa penelitian ini memiliki kebaruan dan urgensi untuk dilaksanakan agar argumen di dalam editorial media massa semakin baik dan kompetensi para penulis editorial semakin meningkat.

Penulisan editorial harus mempertimbangkan konstruksi argumen dengan alur berpikir logis. Menurut Walton (2008) konstruksi argumentasi memperlihatkan hubungan yang logis antara premis-premis dan kesimpulan sehingga membentuk rangkaian yang benar sesuai dengan penalaran baik sehingga mampu menyakinkan pembaca. $\mathrm{Hal}$ ini senada dengan pernyataan $\mathrm{Bal}$ (2014) bahwa konstruksi argumentasi memperlihatkan pernyataan posisi yang diikuti dukungan sampai pada kesimpulan yang tepat. Sementara itu, dalam buku Panduan Kompas (2008) diungkapkan bahwa argumentasi dibangun dengan menyusun alasan secara logis untuk menunjang topik dalam sebuah teks.

Sementara itu, komitmen dalam teks editorial harus muncul dalam pengungkapan argumentasi sehingga argumen menjadi kuat dan tidak terbantahkan. Argument by commitment menunjukkan konsistensi penulis dalam menyampaikan pandangan terhadap situasi aktual yang terjadi di masyarakat. Walton (2005) menyatakan bahwa argument by commitment merupakan salah satu bentuk argumen yang dapat digunakan sebagai cara untuk mengambil kesimpulan bahwa responden konsisten dengan komitmennya. Dia juga menegaskan bahwa argumen berbasis komitmen digunakan untuk membantah komitmen dari penyanggah yang tidak konsisten. Untuk membantah argumen berbasis komitmen, penyanggah dapat menggunakan dukungan. Dukungan tersebut dibutuhkan sebagai premis yang menunjukkan komitmen responden untuk membantah proposisi berdasarkan kesimpulan premis tersebut.

Identifikasi konsistensi argumen dapat ditelusuri melalui penalaran logis antarelemen argumentasi yang digunakan penulis editorial. Toulmin, dkk. (1979) mengemukakan bahwa terdapat enam elemen yang dapat digunakan untuk mengembangkan argumen yang berkualitas, yaitu: (1) pernyataan posisi (claim), (2) data atau fakta (data), (3) jaminan (warrant), (4) dukungan (backing), (5) modalitas (qualifier), dan (6) pengecualian (rebuttal). Lebih lanjut, Setyaningsih (2016) juga mengemukakan bahwa elemen-elemen ini saling berhubungan secara sistematis dan sistemik. Kehadiran elemen-elemen tersebut dalam sebuah argumen saling bersinergi dan menguatkan.

Berdasarkan studi dokumentasi terhadap sejumlah editorial Bisnis Indonesia, ditemukan bahwa editorialeditorial tersebut inkonsisten. Inkonsistensi tersebut dapat diidentifikasi melalui ketidaksesuaian antara elemen klaim dan konklusi dari argumentasi dalam teks editorial. Ketidaksesuaian itu berimplikasi terhadap lemahnya argumentasi sehingga mudah dibantah dan tidak dapat menyakinkan pembaca. Beberapa kendala yang mungkin menjadi faktor penyebab adalah kurangnya pemahaman yang mendalam para penulis editoral mengenai argumen dan argumen berbasis komitmen menurut perspektif Douglas Walton.

Berdasarkan paparan tersebut, dapat disimpulkan bahwa masalah yang diangkat dalam penelitian ini, yakni a) bagaimana konstruksi argument by commitment dalam editorial harian Bisnis Indonesia, b) bagaimana upaya pengoptimalisasian konstruksi argument by commitment sehingga argumentasi dalam 
editorial harian Bisnis Indonesia lebih konsisten, dipercaya, meyakinkan, serta memengaruhi pembaca untuk bertindak atau melakukan sesuatu.

\section{B. METODE}

Penelitian ini bertujuan untuk mendeskripsikan a) konstruksi argument by commitment dalam editorial harian Bisnis Indonesia, dan b) upaya pengoptimalisasian konstruksi argument by commitment. Data penelitian ini berupa argument-argument by commitment yang terdapat pada wacana editorial harian Bisnis Indonesia. Sumber data penelitian ini adalah teks-teks editorial yang dimuat dalam harian Bisnis Indonesia edisi September-Oktober 2019. Teks editorial yang dianalisis sebanyak 10 buah.

Teknik pengumpulan data penelitian ini adalah dokumentasi dan wawancara. Arikunto (2013) menyatakan bahwa studi dokumentasi dapat dilakukan dengan cara 1) membaca harian Bisnis Indonesia, 2) mengoleksi dan mengklasifikasi teks editorial yang akan dianalisis, (3) memberikan kode pada editorial yang akan dianalisis, 4) menandai konstruksi dan elemen argumentasi dalam editorial, 5) merekam data ke dalam tabel analisis, (6) mengelompokkan data berdasarkan pola elemen dan konstruksi argumentasi, 7) memberikan kode, dan 8) melakukan analisis.

Metode analisis data kualitatif diterapkan dalam penelitian ini. Bogdan dan Biklen (dalam Moleong, 2013) menyatakan bahwa analisis data kualitatif merupakan upaya yang dilakukan dengan jalan bekerja dengan data, mengorganisasikan data, memilah-milah yang menjadi satuan yang dapat dikelola, mensintesiskannya, mencari dan menemukan pola, menemukan apa yang penting dan apa yang dipelajari, dan memutuskan yang dapat yang diceritakan kepada orang lain. Peneliti berperan sebagai instrumen kunci penelitian ini karena jenis penelitiannya bersifat kualitatif. Peneliti menggunakan dua jenis instrumen tambahan, yaitu instrumen panduan pengumpulan data dan instrumen panduan analisis data.

\section{PEMBAHASAN}

Berdasarkan hasil analisis terhadap 10 teks editorial ditemukan bahwa 20\% teks editorial yang konsisten dan 80\% teks editorial yang inkonsisten. Tabel 1 menunjukkan bukti konsistensi dan inkonsistensi argument by commitment di editorial harian Bisnis Indonesia. Pada tataran struktur teks, konstruksi berbasis komitmen dalam editorial Bisnis Indonesia dapat diidentifikasi melalui konsistensi antarelemen premis pernyataan posisi dan konklusi. Kesesuaian antarelemen premis pernyataan posisi dan konklusi membuat argumentasi menjadi konsisten. Semakin konsisten argumen yang disampaikan penulis editorial, semakin tinggi tingkat kepercayaan pembaca.

Data pada Tabel 1 memaparkan manisfestasi argumen berbasis komitmen dalam editorial Bisnis Indonesia. Komponen argumentasi teks editorial yang dianalisis mengacu pada enam elemen argumentasi Toulmin, dkk. (1979) yang terdiri dari pernyataan posisi/claim (C), data (D), jaminan/warrant (W), pendukung/backing (B), modallitas/ qualifier (Q), dan bantahan/rebuttal (R).

Argumen yang inkonsisten membuka peluang bagi pembaca untuk menyanggah atau membantah komitmen penulis editorial dalam menyampaikan argumen kepada pembaca. Walton menyatakan bahwa argumen berbasis komitmen merupakan salah satu bentuk argumen yang dapat digunakan sebagai salah satu cara untuk mengambil kesimpulan bahwa argumen penulis konsisten atau tidak konsisten dengan komitmennya. 
Tabel 1. Manisfestasi Inkonsistensi Argument Berbasis Komitmen

\begin{tabular}{clc}
\hline TR & \multicolumn{1}{c}{ Komponen Argumen Berbasis Komitmen } & Komitmen \\
\hline 1 & Pengantar-C-D1-D2-D3-W-R1-R2-D4-R3-R4-Q-D5-R5-R6-Harapan & Inkonsisten \\
2 & C-D1-W-B1-D2-R1-R2-B2-B3-B4-D3-Q-B5-B6-Harapan. & Konsisten \\
3 & C-D1-D2-R-W-B1-B2-B3-B4-B5-B6-B7-B8-B9-Q. & Konsisten \\
4 & C-D1-D2-D3-W1-D4-R1-R2-D5-D6-D7-R3-W2-R4-Q-Harapan & Inkonsisten \\
5 & C-D1-D2-W1-B1-B2-W2-D3-W3-R1-B3-W4-W5-B4-R2-Q & Inkonsisten \\
6 & Pengantar-C-D1-R-D2-W1-B1-B2-D3-W1-W2-Q & Inkonsisten \\
7 & C-D1-D2-D3-W1-B1-D4-D5-W2-Harapan-Harapan-Q & Inkonsisten \\
8 & C-D1-D2-D3-W1-D4-W2-B1-B2-B3-B4-B5-C-Q & Inkonsisten \\
9 & C-D-W1-W2-W3-R-W4-B1-B2-B3-B4-Harapan-Harapan-W5-Harapan-Q & Inkonsisten \\
10 & D1-W1-W1-C-D2-W3-R-D3-D4-W4-Harapan-W5-Harapan-Q-W-Harapan- & Inkonsisten \\
\hline
\end{tabular}

Konsep ini memberikan gambaran bahwa penulis editorial yang tidak konsisten dengan komitmennya membuat argumennya menjadi lemah dan tidak memengaruhi pembaca. Sebaliknya, penulis editorial yang menyampaikan argumen secara konsisten dengan komitmennya hal itu akan berpengaruh kepada pembaca sehingga pembaca yakin dan percaya dengan yang disampaikan penulis editorial. Hal ini selaras dengan pandangan Walton bahwa argumen berbasis komitmen digunakan untuk membantah komitmen dari penyanggah yang tidak konsisten. Oleh karena itu, konsistensi menjadi entitas yang urgen dalam membangun sebuah argumen yang kuat dan terpercaya.

Argumen berbasis komitmen dalam penulisan editorial Bisnis Indonesia dapat dikategorikan dalam dua konstruksi, yakni: 1) konstruksi argument by consistent commitment (argumen berbasis komitmen konsisten), 2) konstruksi argument by inconsistent commitment (argumen berbasis komitmen inkonsisten). Kedua jenis argumen tersebut akan dipaparkan sebagai berikut.

\section{1) Konstruksi Argumen Berbasis Komitmen Konsisten}

Konstruksi argumen berbasis komitmen konsisten merupakan argumen yang tidak banyak ditemukan dalam teks editorial. Argumen ini merupakan salah satu bentuk argumen yang dapat digunakan sebagai salah satu cara untuk mengambil kesimpulan bahwa responden tidak konsisten dengan komitmennya (Walton, 2005). Konsep ini memberikan gambaran bahwa responden yang tidak konsisten dengan komitmennya memperlemah argumentasinya. Namun, jika responden komitmen dengan apa yang telah diungkapkan maka tentu argumentasinya tidak dapat dibantah. Walton (2004) menyatakan bahwa argument by commitment digunakan untuk membantah komitmen dari penyanggah yang tidak konsisten. Untuk membantah argumen dari komitmen, penyanggah dapat menggunakan dukungan. Walton (2005) menegaskan bahwa pendukung dibutuhkan sebagai sebuah premis proposisi yang menunjukkan komitmen responden dan digunakan untuk membantah proposisi responden lain berdasarkan kesimpulan dari premis tersebut.

Konsistensi argumen berbasis komitmen dapat diidentifikasi melalui kesesuaian antara premis pernyataan posisi dan konklusi yang ditarik oleh penulis. Data pada Tabel 2 menunjukkan konsistensi komitmen penulis dalam argumentasi editorial Bisnis Indonesia. 


\section{Tabel 2. Konsistensi Argumen Editorial}

\begin{tabular}{llll}
\hline Kode Data & \multicolumn{1}{c}{ Teks Editorial } & Komitmen \\
\hline & Para pemangku kepentingan di sektor pertekstilan, khususnya & \\
& pengusaha dan asosiasi, semakin cemas terkait dengan lonjakan impor & \\
yang semakin tak terbendung. & & \\
& Skenario penyelamatan sangat penting karena sektor industri ini & Konsisten \\
& menyerap tenaga kerja sekitar 3,58 juta orang, atau mencakup 21,2 dari & \\
& total populasi pekerja di sektor manufaktur. & \\
& & \\
& Harapan tak putus sampai jerat tersentak rantus menjadi peribahasa & \\
& yang tepat untuk menggambarkan kerja keras pemerintah untuk kembali & \\
& menaikkan produksi siap jual (lifting) minyak nasional yang terus & \\
& merosot. & & \\
& Momentum transisi yang kurang dari 2 tahun harus dimanfaatkan & Konsisten \\
& semaksimal mungkin agar produksi di blok tersebut dapat meningkat, & \\
& sehingga membantu pemerintah mencapai target lifting minyak nasional.
\end{tabular}

Kalimat pertama dalam TR2 merupakan premis pernyataan posisi penulis terhadap persoalan yang terjadi. Toulmin, dkk. (1979) menjelaskan bahwa pernyataan posisi adalah pandangan atau pendapat penulis. Data TR2 menunjukkan pandangan penulis bahwa para pemangku kepentingan di sektor pertekstilan, khususnya pengusaha dan asosiasi, semakin cemas terkait dengan lonjakan impor yang semakin tak terbendung yang berakibat pada tersudutnya pabrikan lokal. Pernyataan posisi penulis tersebut merupakan pernyataan posisi berdasarkan fakta. Seyler (2012) menyatakan bahwa fakta dapat menjadi pendukung tetapi juga dapat menjadi pernyataan posisi itu sendiri. Bertolak dari pernyataan posisi tersebut, dengan memaparkan bukti-bukti yang mendukung posisi, penulis kemudian menyatakan sikap bahwa skenario penyelamatan sangat penting karena sektor industri ini menyerap tenaga kerja sekitar 3,58 juta orang, atau mencakup 21,2 dari total populasi pekerja di sektor manufaktur. Pernyataan sikap tersebut tertuang dalam elemen modalitas sebagai premis bukti komitmen. Rybacki \& Rybacki (1991) menyatakan bahwa modalitas menunjukkan kadar kekuatan yang dimiliki pernyataan posisi dalam sebuah argumen. Modalitas dapat berupa keterangan kalimat yang menyatakan sikap pembicara terhadap hal yang dibahas (Toulmin, dkk., 1979). Modalitas yang digunakan penulis dalam TR2 berupa sangat penting. Berdasarkan kedua elemen tersebut maka dapat ditarik kesimpulan bahwa penulis konsisten dengan pernyataan posisi.

Kalimat pertama data TR3 di atas menunjukkan pernyataan posisi penulis yang diungkapkan dengan sebuah peribahasa yang menggambarkan kerja keras pemerintah untuk menaikkan produksi siap jual (lifting) minyak nasional yang terus merosot. Pernyataan posisi tersebut dapat dikategorikan sebagai pernyataan posisi berupa kebijakan. Seyler (2012) menyatakan bahwa pernyataan posisi berupa kebijakan merupakan pernyataan tentang apa yang seharusnya terjadi, apa yang seharusnya atau tidak boleh dilakukan. Sementara itu kalimat kedua menjadi premis bukti komitmen dari penulis terhadap persoalan yang dibahas. Peryataan posisi penulis tersebut sejalan dengan sikap yang diambil penulis dalam kalimat kedua bahwa momentum transisi yang kurang dari 2 tahun harus dimanfaatkan semaksimal mungkin agar produksi di blok tersebut dapat meningkat, sehingga membantu pemerintah mencapai target lifting minyak nasional. Bertolak dari kedua elemen 
tersebut, dapat disimpulkan bahwa komitmen penulis dalam argumentasi tersebut bersifat konsisten.

Jika ditelisik secara seksama, argumentasi dari TR2 dan TR3 dapat dikatakan sebagai argumen berbasis komitmen. Komitmen penulis yang konsisten dengan sikap pembicara terhadap persoalan yang dibahas (perbuatan, keadaan peristiwa) terungkap dalam konklusi. Hal ini selaras dengan pendapat Walton (2005) bahwa kelogisan argumen berbasis komitmen dapat diukur dari konsistensi antara klaim yang diungkapkan dan konklusi yang ditarik dari premis-premisnya. Data TR2 merupakan klaim yang disampaikan penulis. Klaim tersebut konsisten dengan sikap penulis bahwa skenario penyelamatan sangat penting sebagai akibat dari tidak terbendungnya lonjakan impor. Kedua pernyataan tersebut konsisten jika kedua pernyataan tersebut benar (Walton, 2005). Klaim dalam data TR2 tersebut berupa klaim fakta. Hal ini sejalan dengan pandangan Seyler (2012) yang menegaskan bahwa klaim demikian ini merupakan klaim fakta.

Sementara itu, data TR3 menggunakan peribahasa untuk mengungkapkan pernyataan posisi. Klaim tersebut berisi peningkatan produksi lifting minyak nasional oleh pemerintah. Klaim ini dapat dikategorikan sebagai klaim berupa kebijakan karena memberikan gambaran mengenai pernyataan tentang apa yang seharusnya dilakukan dan apa yang tidak boleh dilakukan (Seyler, 2012).

\section{2) Konstruksi Argument by Incon- sistent Commitment}

Berdasarkan hasil analisis, ditemukan konstruksi argument by commitment dalam teks editorial yang inkonsisten (argument by inconsistent commitment) pada media Bisnis Indonesia. Inkonsistensi argument tersebut dapat diidentifikasi melalui ketidaksesuaian antara premis pernyataan posisi dan konklusi yang dibuat oleh penulis. Inkonsistensi argumen tersebut dapat disampaikan pada Tabel 3.

Data TR1 dan data TR7 pada Tabel 3 menunjukkan argumentasi yang inkonsisten dengan komitmen penulis. Hal itu dapat ditelusuri melalui ketidaksesuaian antarelemen yang digunakan dalam teks editorial. Kalimat pertama data TR1 mengungkapkan pernyataan posisi berdasarkan fakta, yakni bahwa sejumlah catatan gemilang di bidang pembangunan infrastruktur berhasil ditorehkan pemerintahan Joko Widodo-Jusuf Kalla selama lima tahun menjabat.

\section{Tabel 3. Inkonsistensi Argumen Editorial}

\begin{tabular}{lll}
\hline Kode Data & \multicolumn{1}{c}{ Teks Editorial } & Komitmen \\
\hline \multirow{4}{*}{ TR1 } & Formulasikan besaran UMP dibarengi dengan filosofi mencari & \\
& titik harmoni antara pengusaha, pekerja, dan pemerintah. & \\
& Dalam situasi yang kurang menguntungkan ini, kenaikan UMP & \\
& 2020 harus tetap dilakukan. Belum lagi jika kenaikan upah ini & Inkonsisten \\
& dibawa dalam ranah politik dalam masa kampaye, tentu situasi & \\
& bakalan makin runyam. & \\
& Sejumlah catatan gemilang di bidang pembangunan infrastruktur & \\
& berhasil ditorehkan pemerintahan Joko Widodo-Jusuf Kalla & \\
& selama lima tahun menjabat. & \\
& Pembangunan yang dilakukan selama 5 tahun lalu mungkin baru & Inkonsisten \\
TR7 & akan berdampak maksimal dalam 5 atau 10 tahun yang akan & \\
datang.
\end{tabular}


Seyler (2012) menyatakan bahwa fakta sekalipun dapat menjadi pendukung pernyataan posisi, juga dapat menjadi pernyataan posisi itu sendiri. Klaim tersebut berkontradiksi dengan sikap penulis yang diidentifikasi melalui elemen modalitas. Hal tersebut menegaskan bahwa pembangunan yang dilakukan 5 tahun lalu mungkin baru akan berdampak maksimal dalam 5 atau 10 tahun ke depan. Konklusi yang dapat ditarik dari kedua elemen tersebut adalah penulis inkonsisten dengan pernyataan posisinya. Hal ini sejalan dengan pendapat Walton (2005) yang menegaskan bahwa dalam kasus sederhana, inkonsistensi dapat disebut kontradiksi jika satu pernyataan berseberangan dengan pernyataan lain.

Argumen dalam data TR1 tersebut juga dapat dikategorikan sebagai argumen dengan derajat kepastian yang lemah. Hal ini dapat diidentifikasikan dengan penggunaan keterangan modalitas 'mungkin' dalam berargumen. Menurut (Ribacky, 1991) modalitas menunjukkan kadar kekuatan yang dimiliki pernyataan posisi dalam argumen. Adapun kata keterangan dan frasa keterangan yang dapat mengindikasikan kekuatan rasional dalam argumen sebagai berikut: seperlunya, dengan pasti, kiranya, dalam semua kemungkinan, sejaub ada buktinya, dari semua yang bisa disebutkan, sepertinya, sangat mungkin, mungkin, rupanya, secara masuk. akal, kelihatannya (Seyler, 2010).

Sementara itu, data TR7 menyampaikan peryataan posisi dalam kalimat pertama, yakni bahwa Presiden Jokowi mengirimkan signal kabinet kerja pada periode pemerintahannya yang kedua akan diisi oleh wajah-wajah muda. Klaim tersebut inkonsisten dengan konklusi bahwa pemerintahan dan kabinet terpilih harus mampu mewujudkan harapan seluruh masyarakat bahwa perekonomian Indonesia akan semakin maju. Kedua kalimat dalam data TR7 dikatakan inkonsisten karena kedua kalimat tersebut tidak menunjukkan hubungan secara logis satu dengan yang lainnya. Hal ini selaras dengan pernyataan Walton, (2005) bahwa proposisi akan menjadi inkonsisten jika keduanya tidak menampilkan hubungan antara satu dan lainnya. Secara kritis dapat diutarakan pertanyaan apakah ada hubungan yang logis antara wajah-wajah baru dengan perekonomian Indonesia yang semakin maju?

Inkonsistensi yang terdapat dalam editorial Bisnis Indonesia di atas memberikan bukti adanya kesalahan dalam argumentasi. Menurut Walton, (2005) inkonsistensi merupakan pratanda penting adanya kesalahan dalam argumentasi kritis.

Bertolak dari inkonsistensi argumen dalam editorial, upaya optimalisasi konstruksi argumen berbasis komitmen mendesak untuk dilakukan. Dengan demikian, argumentasi dalam editorial Bisnis Indonesia menunjukkan alur berpikir logis, sistematis, tajam, terpercaya sehingga dapat meyakinkan pembaca.

\section{3) Upaya Optimalisasi Konstruksi Argumen by Commitment}

Pengoptimalisasian argument by commitment dalam penyusunan editorial di harian Bisnis Indonesia dapat dilakukan dengan beberapa langkah berikut. Pertama, para penulis editorial harus memahami konsep argument by commitment. Pemahaman konsep argumen tersebut sangat penting karena mereka akan memiliki pengetahuan yang mendasar tentang argumen sehingga mampu menerapkan dalam penyusunan argumentasi editorial yang logis dan sistematis. Mereka juga akan mampu menyusun editorial dengan pola dan struktur argumen yang lengkap, runtut, sistemik sehingga substansi argumen editorial bermutu dan dapat dipahami pembaca dengan baik.

Kedua, para penulis editorial harian Bisnis Indonesia harus merancang skema argument by commitment secara cermat. 
Rancangan skema argument tersebut sangat penting dalam menyusun editorial karena dengan rancangan itu, penulis akan mampu menempatkan pokok-pokok argumennya dalam setiap elemen rancangan. Selain itu, penulis editorial akan mampu menyusun argumentasi yang andal, logis, terpercaya, dan tidak terbantahkan oleh pembaca. Dengan cara itu, para penulis editorial juga akan mampu menyusun tulisan yang menginspirasi dan membuka wawasan pembaca. Dalam kaitan dengan itu, Walton (2005) memaparkan bahwa skema argumen merupakan struktur premiskonklusi yang menunjukkan tipe umum argumentasi yang digunakan dalam diskursus sehari-hari seperti bidang hukum dan ilmu pengetahuan. Adapun Winfred F. Hill (2010) menyatakan bahwa skema merupakan cara mempersepsi, memahami, dan berpikir tentang dunia. Dia juga menyebut bahwa hal itu merupakan kerangka atau struktur pengorganisir aktivitas mental. Pendapat itu selaras dengan Robert J. Sternberg (2008) yang mendefinisikan skema sebagai perangkat mental bagi pengorganisasian pengetahuan. Skema memberikan gambaran secara jelas mengenai pengorganisasian argumentasi yang logis dari penulis kepada pembaca.

Argument by commitment diatur dalam skema umum dimana $a$ adalah seorang partisipan dalam dialog dimana A dan B adalah pernyataan seperti digambarkan dalam skema Tabel 4 (Walton, 2005).

Skema argument by commitment di atas memberikan gambaran akan pentingnya konsistensi dalam argument by commitment.
Sebagai contoh, harapan tak putus sampai jerat tersentak rantus menjadi peribahasa yang tepat untuk menggambarkan kerja keras pemerintah untuk kembali menaikkan produksi siap jual (lifting) minyak nasional yang terus merosot. Ketika penulis mengatakan bahwa pemerintah berusaha untuk kembali menaikkan produksi siap jual (lifting) minyak nasional maka penulis editorial berkomitmen untuk mendukung langkah pemerintahan. Pada kasus ini penulis berkomitmen untuk mendukung program kerja Pemerintahan Jokowi Jusuf Kalla. Dalam kasus lain, penelusuran terhadap inkonsistensi argument by commitment tidak hanya dapat diidentifikasi melalui pernyataan yang kontradiktoris tetapi dapat ditelusuri melalui pernyataanpernyataan di mana yang satu menegaskan dan yang lain membantah (Walton, 2005). Sebagai contoh, sejumlah catatan gemilang di bidang pembangunan infrastruktur berhasil ditorehkan pemerintahan Joko Widodo-Jusuf Kalla selama lima tahun menjabat. Pembangunan yang dilakukan selama 5 tahun lalu mungkin baru akan berdampak maksimal dalam 5 atau 10 tahun yang akan datang.

Konsistensi argument by commitment dapat diutarakan melalui kesesuaian antara premis pernyataan-konklusi. Walton (2005) menyatakan bahwa kelogisan argumen dari komitmen dapat diukur dari konsistensi antara klaim yang diungkapkan dengan konklusi yang ditarik dari premis-premis. Semakin konsisten argument by commitment semakin kuat dan tajam argumentasinya.

Tabel 4. Skema Argumen dari Komitmen

\begin{tabular}{lll}
\hline \multicolumn{1}{c}{ Premis bukti komitmen } & \multicolumn{1}{c}{ Premis keterkaitan komitmen } & \multicolumn{1}{c}{ Kesimpulan } \\
\hline Pada kasus ini ditunjukan bahwa a & Umumnya ketika seorang berkomitmen & Pada kasus ini, $a$ \\
komitmen untuk proposisi A, & untuk A, maka dapat disimpulkan bahwa & berkomitmen untuk \\
menurut bukti yang dia katakan atau & ia juga komitmen untuk B. & B. \\
tidak. & &
\end{tabular}


Ketiga, penulis editorial harian Bisnis Indonesia harus mampu mengajukan pertanyaan yang terus-menerus tentang masalah yang akan diargumentasikan dalam editorial. Pertanyaan-pertanyaan tersebut merupakan salah satu bentuk ungkapan daya kritis penanya terhadap apa yang disampaikan. Selain itu, pertanyaan yang terus-menerus disampaikan tersebut akan menuntun penulis editorial menuju hakikat masalah yang diargumentasikan. Menurut Walton (2005) mengajukan pertanyaanpertanyaan merupakan sebuah bentuk kritik terhadap argumentasi. Pertanyaanpertanyaan kritis dapat mengindikasikan adanya keraguan akan kebenaran dari sebuah pernyataan posisi.

Pada sisi yang lain, pembaca juga dapat mengajukan pertanyaan kritis sebagai bentuk kesangsian akan kebenaran editorial. Walton (2005) juga menegaskan bahwa ketika seseorang mengajukan pertanyaan, sesungguhnya orang tersebut mengekspresikan keraguan bahwa sesuatu yang dikatakan itu adalah benar atau bertanya untuk meminta klarifikasi.

Argument by commitment dapat menjadi sebuah argumen yang masuk akal tetapi juga dapat menjadi sebuah argumen yang dapat dibatalkan. Dougas N. Walton (2005) menyatakan bahwa bantahan terhadap argument by commitment dapat dipertimbangkan dengan mengajukan pertanyaan kritis sebagai berikut.

a) Bukti apa dalam kasus yang mendukung pernyataan posisi bahwa a berkomitmen untuk $A$, dan apakah itu termasuk bukti yang bertentangan dimana menunjukkan bahwa a mungkin tidak komitmen untuk A?

b) Adakah ruang untuk mempertanyakan adanya pengecualian dalam kasus ini dengan aturan umum bahwa komitmen A menyiratkan komitmen terhadap B?

Pertanyaan-pertanyaan kritis tersebut dapat diajukan sebagai pembuktian terbalik terhadap komitmen yang diungkapkan penulis untuk sampai kepada sebuah kesimpulan yang tak terbantahkan. Dengan demikian, argumen yang disampaikan penulis menjadi konsisten, kuat, dan menyakinkan pembaca.

\section{PENUTUP}

Dari penelitian yang dilakukan, diperoleh jawaban rumusan masalah pertama penelitian ini, yakni bahwa argument by commitment editorial harian Bisnis Indonesia belum sepenuhnya konsisten. Beberapa fakta inkonsistensi argument by commitment ditemukan peneliti pada sejumlah editorial. Oleh karena itu, langkah-langkah optimalisasi perlu dilakukan. Optimalisasi konstruksi argument by commitment dapat dilakukan melalui tiga langkah: (1) memahami konsep argument by commitment, (2) merancang skema argument by commitment, dan (3) mengajukan pertanyaan kritis.

Penelitian ini memiliki keterbatasan dalam hal jumlah editorial yang dianalisis karena terbatas hanya pada editorial bulan September-Oktober 2019. Penulis berkomitmen untuk melakukan penelitian serupa yang lebih memadai di masa mendatang. Selain itu, peneliti lain yang memiliki minat serupa juga dapat melakukan penelitian tentang hal ini sehingga penelitian tentang argumentasi dalam editorial semakin berkualitas dan bermanfaat bagi pengembangan industri media di Indonesia.

\section{UCAPAN TERIMA KASIH}

Ucapan terima kasih disampaikan kepada Badan Riset dan Inovasi Nasional Kemdikbud yang telah mendukung terlaksananya penelitian ini. Artikel ini sebagai luaran wajib penelitian tersebut. 


\section{DAFTAR PUSTAKA}

Arikunto, S. (2013). Prosedur Peneltian: Suatu Pendekatan Praktis. Jakarta. PT. Rineka Cipta.

Al-Khatib, K., Wachsmuth, H., Kiesel, J., Hagen, M., \& Stein, B. (2016). A News Editorial Corpus for Mining Argumentation Strategies. COLING 2016-26th International Conference on Computational Linguistics, Proceedings of COLING 2016: Technical Papers, 3433-3443.

Bal, B. K. (2014). Analyzing Opinions and Argumentation in News Editorials and Op-eds. International Journal of Advanced Computer Science and Applications, 4(1), 22-29. https://dx.doi.org/10.14569/Speci alIssue.2014.040104

Hill, W. F. (2010). Theories of Learning (Konsepsi, Komparasi, dan Signifikasi). Bandung: Nusa Media.

Anggara, R. F. (2015). Analisis Isi Tajuk Rencana tentang Korupsi di Surat Kabar Harian Kedaulatan Rakyat. Jurnal Ilmu Komunikasi, 13(1), 78-95.

Moleong. L. J. (2013). Meteodologi Penelitian Kualitatif. Bandung: Remaja Rosadakarya

Pertiwi, L. B. (2018). Argumentasi dalam Teks Editorial Harian Suara Merdeka. Basindo: Jurnal Kajian Bahasa, Sastra Indonesia, dan Pembelajarannya, 2(1), 1-13. http://dx.doi.org/10.17977/um00 7v2i12018p001

Padiatra, A. M. (2018). Ketika Pers Bicara Korupsi: Analisis Editorial Harian Pedoman pada Awal Orde Baru 1969-1974. Paradigma: Jurnal Kajian Budaya, 5(2), 103-117. http://dx.doi.org/10.17510/paradi gma.v5i2.51

Rybacki, K, C. \& Rybacki, D. J. (1991). Advocacy and Opposition: An
Introduction to Argumentation.

Prentince Hall: Englewood Cliffts.

Sembiring, J. \& Surya, E. (2017). Penerapan Pembelajaran Kontekstual (CTL) untuk Meningkatkan Pemahaman Konsep Matematika Siswa pada Materi Himpunan di Kelas VII SMP Muhammadiyah 2 Medan. FMIPA UNIMED.

Seyler, D. U. (2012). Read, Reason, Write: An Argument Text and Reader. New York: McGraw-Hill.

Setyaningsih, Y. (2016). Pola Argumen Paragraf Argumentatif pada Artikel Jurnal Terakreditasi Bidang Ekonomi (Perspektif Logika Toulmin). Adabiyyat, 15(2), 136156.

https://doi.org/10.14421/ajbs.201 6.15202

Stenberg, R. J. (2008). Psikologi Kognitif. Yogyakarta: Pustaka Pelajar.

Sudjana, N. (2011). Penilaian Proses Hasil Belajar Mengajar. Bandung: Remaja Rosdakarya.

Toulmin, S., Rieke, R., \& Janik, A. (1979). An Introduction to Reasoning. New York: Macmillan Publishing.

Tim Buku Kompas. (2008). Buku Panduan Kompas. Jakarta: Penerbit Buku Kompas.

Walton, D. N. (2004). Argumentation Schemes and Historical Origins of the Circumstantial Ad Hominem Argument. Argumentation, 18(3), 359-368.

https://doi.org/10.1023/B:ARGU. 0000046706.45919 .83 .

Walton, D. (2005). Fundamentals of Critical Argumentation. Cambridge: Cambridge University Press. https://doi.org/10.1017/CBO9780 511807039

https://kbbi.kemdikbud.go.id/entri/paha m, diakses pada 6 Maret 2020. 
